\title{
Нетипові прояви хвороби Вільсона - Коновалова (клінічний випадок)
}

\author{
О.Д. Шульга ${ }^{1,2}$, В.А. Гриб ${ }^{3}$, О.А. Юрко ${ }^{4}$, П.В. Потапович', М.Ю. Купновицька-Сабадош ${ }^{3}$ \\ 'КП «Волинська обласна клінічна лікарня» Волинської обласної ради, Луцьк, Україна \\ ${ }^{2}$ Волинський національний університет імені Лесі Українки, Луцьк, Україна \\ ${ }^{3}$ Івано-Франківський національний медичний університет, Івано-Франківськ, Україна \\ ${ }^{4}$ КП «Ківерцівська центральна лікарня» Ківерцівської міської ради, Ківерці, Україна
}

\begin{abstract}
Анотація. Хвороба Вільсона - рідкісне генетичне захворювання, яке доцільно розглядати в диференційній діагностиці за наявності у пацієнта неврологічних, психіатричних та/або печінкових проявів. Найчастішим проявом ураження печінки при хворобі Вільсона $\epsilon$ повільно прогресуюча печінкова недостатність із цирозом, асцитом, варикозним розширенням вен стравоходу, спленомегалією. Симптоми ураження нервової системи часто неспецифічні та включають поведінкові, особистісні і когнітивні порушення, рідше тремор, дизартрію та дисфонію. У статті розглянуті сучасні аспекти етіології, патогенезу, клініки, діагностики хвороби Вільсона, а також представлене власне клінічне спостереження випадку вперше виявленої гепатолентикулярної дегенерації у пацієнтки віком 29 років. Наведений клінічний випадок цікавий ураженням стовбуру головного мозку (моста) на фоні типового ураження базальних гангліїв.

Ключові слова: хвороба Вільсона, гепатолентикулярна дегенерація, мідь, метаболізм, патогенез.
\end{abstract}

\section{Вступ}

Хвороба Вільсона (ХВ) - нейродегенеративне аутосомнорецисивне захворювання, в основі якого лежить порушення метаболізму міді [1].У 1912 р. Самуель Вільсон (Samuel Wilson) опублікував детальний опис захворювання, що тепер носить його ім'я. 3 роками знання щодо ХВ зростали, змінювалося розуміння патогенезу захворювання. Основу патогенезу ХВ становить інактивація АТР7В (мембранний білок, який транспортує мідь), що зумовлює недостатню біліарну екскрецію міді і накопичення її в печінці, головному мозку та інших органах. Дефект нормального включення міді до церулоплазміну призводить до утворення пептиду, який має коротший період напівжиття і, як наслідок, зниження плазматичної концентрації церулоплазміну [1]. XВ пов'язана з мутацією гена, розташованого на 13-й хромосомі (ділянка 13q14-q21), який кодує транслоказу АТР7В Си (мідьтранспортувальну АТФазу Р-типу) [2]. Відомо >520 мутацій гена, більшість осіб $\epsilon$ гетерозиготними за цим захворюванням [3]. Поширеність гепатолентикулярної дегенерації серед дорослих пацієнтів з неврологічними симптомами становить 1 випадок на 30 тис. населення. У більшості випадків ХВ маніфестує у віці 5-35 років [4]. Морфологічною основою $\epsilon$ набряклі астроцити, які вдається виявити в постмортальних зразках тканин [1].

Симптоми хвороби зазвичай корелюють із ураженим органом, проте найвищий рівень патологічного накопичення міді відмічають у печінці і нервовій системі (включаючи рогівку ока) [5]. Найчастішим проявом ураження печінки $\epsilon$ повільно прогресуюча печінкова недостатність із цирозом, асцитом, варикозним розширенням вен стравоходу, спленомегалією. Гостра печінкова недостатність із коагулопатією, енцефалопатією, набряком головного мозку менш характерна для ХВ і відмічається у $5 \%$ пацієнтів, переважно жінок молодого віку [3].

Лушпина - найбільш схильна до ураження ділянка головного мозку. ІІї пошкодження пов'язане з виникненням дистонії, симптомів паркінсонізму, причому залучення у процес блідої кулі веде до виникнення різноманітних дискінезій [1]. Іншими проявами захворювання можуть бути тремор, дизартрія, дисфонія, підвищене слиновиділення, епілепсія, атаксія, порушення постави. Психіатричні прояви ХВ зазвичай пов'язані з ураженням базальних гангліїв, оскільки на рівні останніх відбувається взаємодія моторних, когнітивних і мотиваційних систем. Типовими симптомами $\epsilon$ поведінкові, особистісні і когнітивні порушення. Класичними офтальмологічними ознаками ХВ $\epsilon$ кільце Кайзера - Флейшера і соняшникоподібна катаракта [5].

Жоден із доступних лабораторних тестів не $\epsilon$ специфічним для гепатолентикулярної дегенерації. Діагностична шкала для XВ запропонована робочою групою на 8-му Міжнародному з'їзді з хвороби Вільсона (Лейпциг, 2001) та включена до настанови Європейської асоціації з дослідження печінки (EASL) щодо хвороби Вільсона [6]. Магнітно-резонансна томографія (МРТ) головного мозку - найбільш цінний нейровізуалізаційний метод, який застосовують у діагностиці ХВ. У пацієнтів із неврологічними проявами зміни на МРТ відмічають у всіх випадках, з печінковими - у 42-70\% [5].

Зважаючи на рідкісність XВ, варіабельність клінічних форм, складність діагностики та лікування цього захворювання, наводимо випадок з власної клінічної практики.

\section{Клінічний випадок}

Пацієнтка П., 29 років. Госпіталізована в неврологічне відділення КП «Волинська обласна клінічна лікарня» Волинської обласної ради зі скаргами на порушення мови (відокремлені склади, повільна тиха вимова). 3 анамнезу відомо, що хворіє близько 3 міс, відколи з'явилося затерпання лівої половини обличчя та лівої руки, яке тривало тиждень і самостійно минуло, після чого виникло порушення мови. Напередодні пацієнтка відзначала харчове отруєння, спричинене вживанням сушених кальмарів.

Неврологічне обстеження на момент поступлення. Свідомість ясна. Орієнтована в просторі, часі, особистості. Очні щілини, зіниці $\mathrm{D}=\mathrm{S}$. Рухи очними яблуками в повному об'ємі. Ністагм відсутній. Носогубні складки симетричні. Слух, нюх, смак - збережені. Язик - по середній лінії. Акт ковтання не порушений. Мова дизартрична. Сухожилкові рефлекси симетричні, помірно жваві. Патологічних знаків не виявлено. Сила у м'язах рук та ніг збережена. Координаторні проби виконує нечітко. Стійка в позі Ромберга. Функція тазових органів не порушена. Менінгеальні знаки відсутні.

Об'єктивно. Загальний стан середньої тяжкості. Шкіра з ділянками вітиліго. Видимі слизові оболонки рожевого кольору. Перкуторно над легенями ясний легеневий звук, аускультативно дихання везикулярне над усією поверхнею легень. Артеріальний тиск 120/80 мм рт. ст., частота серцевих скорочень 74 уд./Хв, пульс ритмічний, задовільного наповнення. Живіт правильної форми, неболючий при поверхневій пальпації. Перкуторно нижній край печінки виступає з-під реберної дуги на 2 см, край щільний, загострений, неболючий. Симптом Пастернацького негативний з обох боків.

Лабораторне дослідження. Загальний аналіз крові: еритроцити $-4,3 \cdot 10^{12} / л$, гемоглобін - 132 г/л, гематокрит - 0,39, тромбо-

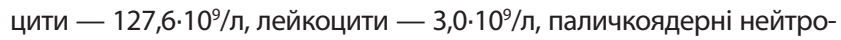
філи - 0\%, сегментоядерні нейтрофіли - 53\%, лімфоцити - 40\%, моноцити - 7\%, швидкість осідання еритроцитів - 8 мм/год.

Біохімічний аналіз крові: глюкоза - 5,6 ммоль/л, загальний білірубін - 9,0 мкмоль/л, непрямий білірубін - 6,9 мкмоль/л, 
прямий білірубін - 2,1 мкмоль/л, сечовина - 2,9 ммоль/л, креатинін - 61 мкмоль/л, аспартатамінотрансфераза - 31 Од/л, аланінамінотрансфераза - 23 Од/л.

Аналіз спинномозкової рідини: прозора, безбарвна, білок 0,28 г/л, реакція Панді від'ємна, цироз - 2 клітини в 1 мм³, еритроцити - 5 клітин в 1 мм³ $^{3}$ глюкоза - 2,89 ммоль/л.

Ультразвукове дослідження органів черевної порожнини: печінка змінена - ехогенність тканини підвищена. Неоднорідна за рахунок помірно виражених дрібновогнищевих фіброзних змін та ділянок зниженої ехогенності. Збільшена на 2 см за рахунок фіброзних змін та ділянок зниженої ехогенності. V. porta розширена, 15 мм, контури горбисті. Жовчний міхур: норма. Підшлункова залоза: візуалізується на всій довжині, ехогенність підвищена за рахунок помірно виражених фіброзних змін. Селезінка: збільшена, $140 \times 70$ мм, селезінкова вена - 9 мм. Права нирка: норма. Ліва нирка: норма.

Відеоезофагогастродуоденоскопія: патології стравоходу, шлунку чи дванадцятипалої кишки не виявлено.

Консультація гастроентеролога, діагноз: «Цироз печінки нез'ясованого генезу, клінічна стадія А (за Чайлдом - П'ю). Портальна гіпертензія I ст., гепатолієнальний синдром, гепатоцелюлярна недостатність 0 ст.».

Консультація офтальмолога: виявлено міопатію слабкого ступеня обох очей (Vis OU=0,9).

На МРТ головного мозку: ураження базальних ядер головного мозку (за типом інтоксикаційних уражень), гідроцефалія незначного ступеня (рисунок).

Враховуючи скарги (повільна тиха вимова слів складами), анамнез захворювання (затерпання лівої половини обличчя та лівої руки, порушення мови, отруєння сушеними кальмарами), об'єктивного обстеження (мова дизартрична, нечіткість виконання координаторних проб; перкуторно нижній край печінки виступає 3-під реберної дуги на 2 см, край щільний, загострений, неболючий), дані інструментальних досліджень (печінка змінена - ехогенність тканини підвищена; неоднорідна за рахунок помірно виражених дрібновогнищевих фіброзних змін та ділянок зниженої ехогенності, збільшена на 2 см за рахунок фіброзних змін та ділянок зниженої ехогенності; v. porta розширена, 15 мм, контури їі горбисті; селезінка збільшена), встановлено діагноз: «Хронічне дегенеративне захворювання базальних гангліїв із дизартрією та вираженою церебрастенією. Цироз печінки нез'ясованого генезу, клінічна стадія А (за Чайлдом - П'ю). Портальна гіпертензія I ст., гепатолієнальний синдром, гепатоцелюлярна недостатність 0 ст.».

Під час перебування пацієнтки у стаціонарі отримано результати лабораторних досліджень: церулоплазмін у сироватці крові 0,03 г/л (норма 0,2-0,6 г/л), негативні маркери на вірусні гепатити.

Встановлено остаточний клінічний діагноз: «Хвороба Вільсона, або гепатолентикулярна дегенерація. Цироз печінки нез'ясованого генезу, клінічна стадія А (за Чайлдом - П'ю). Портальна гіпертензія I ст., гепатолієнальний синдром, гепатоцелюлярна недостатність 0 ст.».

Пацієнтці призначено дієту з виключенням продуктів, що містять мідь, пеніциламін і вітамін $\mathrm{B}_{6}$. Дано рекомендації щодо подальшого спостереження у лікаря.

\section{Обговорення клінічного випадку}

XВ - рідкісне генетичне захворювання, яке повинне розглядатися в диференційній діагностиці за наявності у пацієнта неврологічних, психіатричних та/або печінкових проявів. Особливістю клінічного випадку $\epsilon$ те, що ураження гепатобіліарної системи і селезінки, визначені за даними ультрасонографії, симптомів цирозу печінки не виявлено. Неврологічні порушення якпочатковий прояв захворювання відмічають у 40-60\% випадків, печінкові - у 40-59\% [3]. Наша пацієнтка звернулася зі скаргами на порушення вимови слів, тобто основним було ураження нервової системи. Дизартрія як перший симптом відмічається у $46 \%$ випадків ХВ. Залежно від локалізації ураження і домінантного клінічного симптому порушення мови може мати такі форми: 1) поєднана, 2) атактична (мозочкова), 3) дистонічна (гіперкінетична), 4) гіпокінетична (паркінсонічна), 5) спастична (псевдобульбарна) [5].У наведеному клінічному випадку дизартрія була поєднана (атактична і гіпокінетична). В одному з до- сліджень кільце Кайзера - Флейшера виявлено у 100\% пацієнтів із неврологічними проявами, у 86\% - 3 печінковими [7]. Цікавим $\epsilon$ те, що, незважаючи на превалювання неврологічних проявів, корнеального відкладення пігменту не відмічено. За бальною системою діагностики XВ, що прийнята на 8-му Міжнародному з'їзді з хвороби Вільсона (Лейпциг, 2001), діагноз підтвердити не вдалося, оскільки в Україні обмежене дослідження міді в паренхімі печінки і генетичне тестування. Однак за порівнянням результатів лабораторних тестів $з$ даними атомної абсорбційної спектрометрії біоптатів печінки пацієнтів з гепатолентикулярною дегенерацією з визначенням концентрації міді підтверджено, що чутливість визначення в сироватці крові вмісту міді та церулоплазміну, добової екскреції міді з сечею становить 85; 83 та 53\% відповідно [8].У нашої пацієнтки результати лабораторних обстежень підтвердили діагноз. Характерні МРТ-ознаки при ХВ «лице гігантської панди» або «лице малої панди» притаманні для невеликої кількості випадків [3]. Однак наш випадок особливий тим, що на МРТ-картині наявне мостове ураження з гіпоінтенсивністю центральних покришкових трактів і гіперінтенсивністю відкриття акведуктуса в четвертий шлуночок. Оскільки дизартрія може розвиватися внаслідок ураження базальних гангліїв (екстрапірамідна система), ядер мозочка (та їхніх трактів) і верхніх моторних нейронів (ядра стовбура або пірамідні тракти), то диференційну діагностику ми проводили із захворюваннями, при яких також спостерігається ураження цих структур, а саме: розсіяний склероз, атаксія Фрідрейха, хвороба Крейтцфельдта - Якоба, паркінсонізм [9].У нашої пацієнтки результати МРТ головного мозку і наявна картина виключили деякі з цих захворювань. В анамнезі життя відсутні факти щодо алкогольної хвороби печінки або медикаментозно-індукованого ураження печінки. Однак можливий «overlap»-синдром за наявності вірусного або аутоімунного гепатиту [10].У нашої пацієнтки антитіла до гепатиту A, HBsAG, anti-HCV були негативними.

Лікування ХВ можна розділити на 2 види: лікування симптоматичних і асимптоматичних пацієнтів. Раціональність такого розподілу полягає в тому, що у перших захворювання прогресує швидше, ураження печінки збільшується з тривалістю хвороби. У пацієнтів без симптомів метою терапії $\epsilon$ попередження розвитку проявів захворювання, допомога в цьому випадку не $є$ ургентною порівняно з хворими, які мають печінкові і неврологічні прояви. Після початкового лікування симптоматичні пацієнти стають стабільними або асимптомними і лікування розглядається як підтримувальне.

Згідно з протоколами лікування використовують хелатну терапію, що включає пеніциламін або тріентин, які спрямовані на збільшення сечової екскреції міді. Стадія початкової терапії не обмежена часовими рамками [10]. Нашій пацієнтці призначено пеніциламін 250 мг/добу з поступовим (кожні 4-7 днів) підвищенням дози, а також вітамін В 50 мг/добу, оскільки при застосуванні пеніциламіну часто розвивається недостатність піридоксину.

Звертає увагу отруєння пацієнтки сушеними кальмарами, оскільки саме вони стали тригерним фактором розвитку захворювання. За вмістом міді цей продукт знаходиться на 4-му місці після печінки тріски, какао-порошку і яловичої печінки [11]. Тому великого значення набувало дотримання пацієнткою дієти з виключенням продуктів, багатих на мідь: горіхи, шоколад, гриби, печінка. У пацієнтів із неврологічними проявами ХВ усунення симптомів відбувається повільніше, іноді позитивні зміни стають помітні тільки після 3 років лікування [12]. Моніторинг терапії полягає в оцінці ефективності, дотриманні пацієнтом лікування і контролі побічних реакцій [10].Для своєчасного виявлення побічних ефектів хелатної терапії необхідно контролювати клінічний аналіз крові (включаючи рівень тромбоцитів) і загальноклінічний аналіз сечі з початку лікування кожні 3 дні, потім щотижня протягом місяця, 1 раз на 2 тиж протягом перших 6 міс лікування, в подальшому - щомісяця; біохімічні показники крові (загальний білірубін, аланінамінотрансфераза, аспартатаміно-трансфераза, лужна фосфатаза, креатинін, сечовина) в стадії початкової терапії - 1 раз на 3 міс, надалі - 1 раз на пів року. Не менше ніж 1 раз на рік слід здійснювати рентгенологічне або ультразвукове дослідження нирок і сечовивідних шляхів [11].

Більшість лікарів вважають ХВ дуже рідкісним захворюванням i, як правило, не враховують ї̈ в диференційній діагностиці захворювань печінки і нервової системи. Однак це рідкісне генетичне за- 
Рисунок Гіперінтенсивні ділянки ураження в режимі T2W, FLAIR в стовбурі головного мозку (А-Б) та базальних гангліях (B-Г)

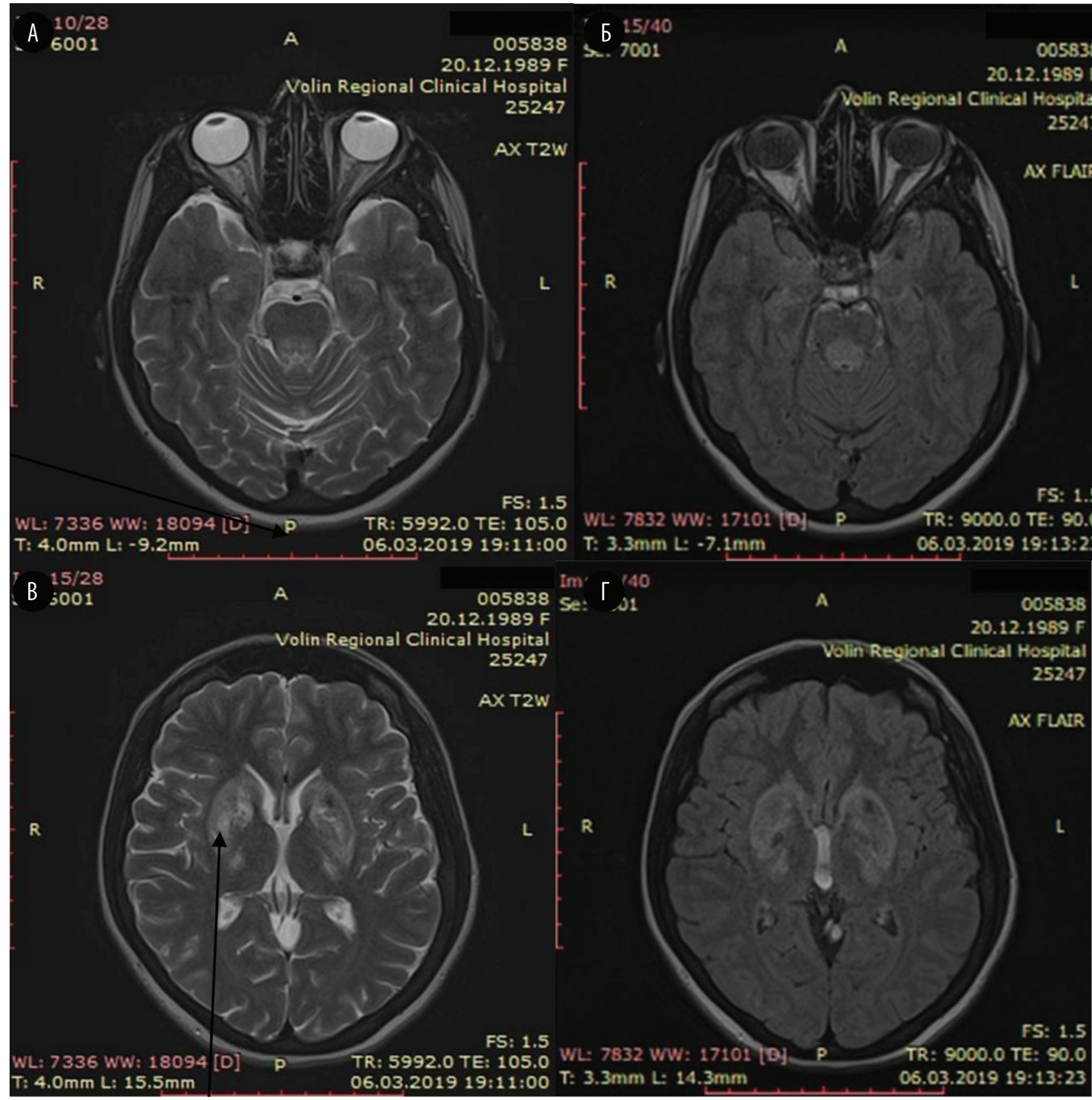

хворювання слід брати до уваги за наявності у пацієнта печінкових, неврологічних і психіатричних проявів. Серед лабораторно-інструментальних методів перші місця за актуальністю посідають виявлення кілець Кайзера - Флейшера за допомогою щілинної лампи та лабораторні тести з визначенням церулоплазміну в сироватці крові, добової екскреції міді з сечею, «вільної» міді в сироватці крові, концентрації міді в тканині печінці. МРТ головного мозку — найцінніший нейровізуалізаційний метод, який використовують при діагностиці ХВ. Адекватне лікування хелаторами міді слід негайно розпочати після діагностики захворювання і продовжувати протягом усього життя, аби уникнути незворотних наслідків ураження печінки і нервової системи. Важливий моніторинг лікування з метою його ефективності та уникнення розвитку небажаних побічних реакцій препаратів.

\section{Список використаної літератури}

1. Scheiber I.F., Brůha R., Dušek P. (2017) Pathogenesis of Wilson disease. Handb. Clin. Neurol., 142: 43-55. doi: 10.1016/B978-0-444-63625-6.00005-7.

2. Stapelbroek J.M., Bollen C.W., van Amstel J.K. et al. (2004) The H10690 mutation in ATP7B is associated with late and neurologic presentation in Wilson disease: results of a meta-analysis. J. Hepatol., 41(5): 758-763. doi: 10.1016/j.jhep.2004.07.017.
3. Pfeiffer R.F. (2016) Wilson Disease. Continuum (Minneap. Minn.),22(4 Movement Disorders): 1246-1261. doi: 10.1212/CON.0000000000000350.

4. www.dec.gov.ua/wp-content/uploads/2019/11/2016_769_ykpmd_vils.pdf.

5. Członkowska A., Litwin T., Chabik G. (2017) Wilson disease: neurologic features. Handb. Clin. Neurol., 142: 101-119. doi: 10.1016/B978-0-444-63625-6.00010-0.

6. EASL (2012) Clinical Practice Guidelines: Wilson's disease. J. Hepatol., 56: 671-685.

7. Taly A.B., Meenakshi-Sundaram S., Sinha S. et al. (2007) Wilson disease: description of 282 patients evaluated over 3 decades. Medicine (Baltimore), 86(2): 112-121. doi: 10.1097/ MD.0b013e318045a00e.

8. Mahjoub F., Fereiduni R., Jahanzad I. et al. (2012) Atomic Absorption Spectrometry in Wilson's Disease and Its Comparison with Other Laboratory Tests and Paraclinical Findings. Iran J. Pediatr., 22(1): 52-56. PMID: 23056859.

9. Hermann W. (2019) Classification and differential diagnosis of Wilson's disease. Ann. Transl. Med., 7(Suppl. 2): S63. doi: 10.21037/atm.2019.02.07.

10. Schilsky M.L. (2017) Wilson Disease: Diagnosis, Treatment, and Follow-up. Clin. Liver Dis., 21(4): 755-767. doi: 10.1016/j.cld.2017.06.011.

11. search.ligazakon.ua/__doc2.nsf/link1/MOZ26291.html.

12. Brewer G.J., Terry C.A., Aisen A.M., Hill G.M. (1987) Worsening of neurologic syndrome in patients with Wilson's disease with initial penicillamine therapy. Arch. Neurol., 44(5): 490-493. doi: 10.1001/archneur.1987.00520170020016. 


\section{Atypical manifestations of Wilson - Konovalov disease (clinical case)}

\section{O.D. Shulga ${ }^{1,2}$, V.A. Gryb ${ }^{3}$, O.A. Yurko ${ }^{4}$, P.V. Potapovych',} M.Yu. Kupnovytska-Sabadosh ${ }^{3}$

'Volyn Regional Clinical Hospital of the Volyn Regional Council, Lutsk, Ukraine

${ }^{2}$ Volyn National Medical University named after Lesya Ukrainka, Lutsk, Ukraine

${ }^{3}$ Ivano-Frankivsk National Medical University, Ivano-Frankivsk, Ukraine ${ }^{4}$ Kivertsi Central Hospital of Kivertsi City Council, Kivertsi, Ukraine

Abstract. Wilson's disease is a rare genetic disoder that should be considered in the differential diagnosis if the patient has neuro-

\section{Відомості про авторів:}

Шульга Ольга Дмитрівна - доктор медичних наук, завідувач неврологічного відділення КП «Волинська обласна клінічна лікарня» Волинської обласної ради, кафедра клінічної медицини Волинського національного медичного університету імені Лесі Українки, Луцьк, Україна. Гриб Вікторія Анатоліївна - доктор медичних наук, професор, завідувач кафедри неврології та нейрохірургії Івано-Франківського національного медичного університету, Івано-Франківськ, Україна.

Юрко Олена Андріївна — лікар-невропатолог, КП «Ківерцівська центральна лікарня» Ківерців ської міської ради, Ківерці, Україна.

Потапович Петро Васильович — лікар-невропатолог, КП «Волинська обласна клінічна лікарня» Волинської обласної ради, Луцьк, Україна.

Купновицька-Сабадош Марта Юріївна — кандидат медичних наук, доцент кафедри неврології та нейрохірургії Івано-Франківського національного медичного університету, Івано-Франківськ, Україна.

Адреса для кореспонденціі:

Шульга Ольга Дмитрівна

43005, Луцьк, просп. Президента Грушевського, 21

E-mail: shulgaolga@ukr.net logical, psychiatric and/or hepatic manifestations. The most common manifestations of liver damage in Wilson's disease are slowly progressive liver failure with cirrhosis, ascites, varicose veins of the esophagus, splenomegaly. Symptoms of nervous system damage are often nonspecific and include behavioral, personality, and cognitive impairment, less often tremor, dysarthria, and dysphonia. The article considers modern aspects of etiology, pathogenesis, clinic, diagnosis of Wilson's disease, as well as our own clinical observation of the case of newly detected hepatolenticular degeneration in a 29-year-old patient. This clinical case is interesting for the lesion of the brain stem (bridge) on the background of a typical lesion of the basal ganglia.

Key words: Wilson's disease, hepatolenticular degeneration, copper, metabolism, pathogenesis.

\section{Information about the authors:}

Shulga Olga D. - Doctor of Medical Sciences, Head of the Neurological Department of the Volyn Regional Clinical Hospital of the Volyn Regional Council, Department of Clinical Medicine, Volyn National Medical University named after Lesya Ukrainka, Lutsk, Ukraine. Gryb Viktoriia A. - Doctor of Medical Sciences, Professor, Head of the Department of Neurology and Neurosurgery, Ivano-Frankivsk National Medical University, Ivano-Frankivsk, Ukraine.

Yurko Olena A. — neurologist, Kivertsi Central Hospital of Kivertsi City Council, Kivertsi, Ukraine.

Potapovych Petro V. — neurologist, Volyn Regional Clinical Hospital, Volyn Regional Council, Lutsk, Ukraine.

Kupnovytska-Sabadosh Marta Yu. — Candidate of Medical Sciences, Associate Professor of the Department of Neurology and Neurosurgery, Ivano-Frankivsk National Medical University, Ivano-Frankivsk, Ukraine.

Address for correspondence:

Olga Shulga

43005, Lutsk, President Hrushevsky ave, 21

E-mail:shulgaolga@ukr.net 